\title{
THE FORMATION AND INFLUENCE OF THE MILITARY ARCHITECTURE IN OMAN DURING AL-YA'ARIBA PERIOD (1034-1162 AH/1624-1749 AD)
}

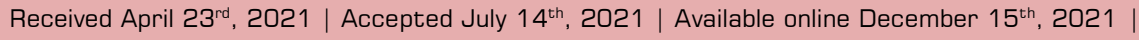

DOI http://dx. doi. org/10.18860/jia.v6i4.12104

Naima Benkari

Sultan Qaboos University,

Muscat,

Sultanate of Oman

nbenkari@squ.edu.om

\begin{abstract}
Despite its richness, the research corpus published about Islamic architecture presents some discontinuities in the knowledge of the architecture in the lands ruled by Muslims. Similarly, the dynamics of influence that might have operated between the "monumental" architecture in these lands and their popular architectures are insufficiently addressed. Moreover, the material culture related to the Islamic civilization is almost exclusively studied as a product that has stopped evolving. The architecture produced during Al-Ya'ariba (Al- Ya'rubi) Imamate (1624-1749) is an instance of these understudied topics in the history of Islamic architecture. This research argues that Al-Ya'rubi Imamate is not only an important chapter in the history of Oman, the Arabian Peninsula, Indian Ocean, and Eastern Africa, but also the architecture of this period has created the identity of Omani architecture as we know it today. Nonetheless, there is no architectural production in this era both in the major references and scientific publications of Islamic architecture in the 17th and 18th centuries. Through field research, comparative analysis, and literature review of the history of Omani architecture, especially in the 17th -18 th centuries, this research examines the military architecture in Oman during Al-Ya'ariba Imamate including its reference, and its influence on other architectures. It is a contribution to the scientific endeavour to address this specific architectural typology from the perspective of its mechanism of (trans) formation and its continuity of forms until the contemporary architecture of Oman
\end{abstract}

\section{KEYWORDS:}

Al-Ya'ariba; Architectural Identity; Defensive Architecture; Forts Typology; Ibadi Imamate; Islamic Architecture; Military Architecture; Oman.

\section{INTRODUCTION}

The scientific literature broadly covers the material production of the Islamic civilization. The first European exploration of the "mysterious" Orient marked the starting of this field of research, which is called Oriental research. It is also covered Islamic architecture. The first publications are mainly produced by architects, historians, artists, army officers, and diplomats who travelled to discover these lands and their exotic cultures. They rely on the description of Arabic literature translation, or even copied the description of other voyagers [1]. The produced historiography is marked and mainly remembered. So, by the attraction, the first publications had the "highprofile" or "monumental" architecture. Indeed, from the late 18th century until today, the masterpiece of Islamic architecture features the typology of the "monumental" buildings (Palace, Mosque, Garden, tomb, shrine, Caravansary, and city). The wide repertoire of the Islamic Arts and architecture is classified and presented following the chronology of the most influential and architecturally productive dynasties and States that make Islam as the source of law and the religion of the population majority. Most textbooks and encyclopedias are dedicated to showcase the "Islamic architecture" scrupulously documented, analysed and described their monuments. However, this rich and long-established field of research still presents some knowledge biases and discontinuities, which need to be addressed to refine our understanding of this topic. First, the material culture related to the Islamic civilization is almost exclusively studied as a finished product, a "legacy of the past" that has stopped evolving. On the contrary, it should be examined as an evertransforming and still-evolving phenomenon. Second, there is an important knowledge gap about the architecture of the people who lived in land ruled by Muslims and even under the most studied Islamic dynasty [2]. The same observation is valid regarding the dynamics of influence that might have operated between the architecture of "monuments", ordered by the powerful rulers or influential patrons in these dynasties, and the popular architecture surrounding them. Finally, in reason of the concentration of 
research on the "monumental" architecture in the region and period where it is the most frequent and best conserved, the vast corpus produced about the Islamic architecture suffers from discontinuity in the research of some periods and regions [1]-[3].

As a contribution to fill this gap, this research addresses the military architecture in Oman under AlYa'ariba Imamate (1624-1744). This period marks the start and expansion of the Omani Empire and lasted for more than a century. Under the banner of AlYa'ariba Imamate, Omanis defeated the Portuguese and liberated the country's coastal cities and the shores of South-East Asia and the Eastern coast of Africa [4] [5]. Nonetheless, this dynasty was absent from the major references and scientific publications of Islamic architecture in the $17^{\text {th }}$ and $18^{\text {th }}$ centuries. Those references addressed in profusion the imperial architecture of the Ottomans, the Mughal and the Safavid, while omitting to study the architecture developed, in Oman, during the same period. It could be because there are no or a few "monuments" in the sense of the definition developed since the early scientific works about Islamic Architecture, which implies the image of a counterpart of the monumental architecture in Europe. That is a building with highly sophisticated architectural expression and extensive decorations. This reductive idea has to be questioned. There are important buildings in the repertoire of Islamic architecture that seem to be concealed in their urban context because of the few features that differentiate them from the popular architecture surrounding them.

This research contributes to the Omani Military architecture by examining the mechanisms of influence exerted by the architecture of the "rulers" upon the one produced by the people. It aims to examine the process of (trans)formation of the Omani military architecture during the Al-Ya'ariba (or AlYa'rubi) period. It is argued that the architecture produced under Al-Ya'ariba Imams become a symbol of the Omani adhesion to the meaning of strength and social cohesion encapsulated, at least in the times when the elected Imam exerted their power through the allegiance "Bay'a" bestowed upon them by their people. This research aims to reveal the continuity of these architectural forms and details in contemporary Omani architecture and how they are linked to the history and geography of this country and the social organization of its people. After the late Sultan Qaboos B. Said's demise (from 1970 to 2020), the country is entering a new era in the political, economic, and architectural history. In such transitional circumstances, this research is a timely opportunity to review and analyze the formation of the country's architectural identity and some of its main characteristics.

The research is composed of eight sections: the introduction, a review of the literature that studied the Omani military architecture that will set the theoretical framework for this research, and the methodology. It is followed by an overview of the historical, political, religious, and socio-economic context in Oman right before and during the Ya'rubi Imamate, then a discussion of the transformation of the military architecture in Oman during al-Ya'ariba Imamate. The architectural typology of the Omani forts and their development will then be presented by emphasizing the description of the Ya'rubi fort typology. Finally, this research will discuss the prevalence of al-Ya'arubi military architectural forms in the Omani architectural identity.

\section{REVIEW OF THE LITERATURE ABOUT THE OMANI MILITARY ARCHITECTURE}

The research of Al-Ya'ariba's architectural production is started relatively late if it is compared to the contemporary States such as the Ottomans, the Mughal, or the Safavid. Some important Omani cities and buildings are described in early voyagers' chronicles and military reports [5]-[11]. However, the scientific research of the architecture during this period has been initiated by the emergence of Oman as a "modern" State under the late Sultan Qaboos Bin Said Al Said. Published studies are mainly funded by the newly established Ministry of National Heritage and Culture, most importantly, through its Journal of Oman Studies (JOS) and many other commissioned works, merely descriptive essays or photography books. We owe the seminal works about the local architecture in Oman to archaeologists, Anthropologists, Historians, Art Historians, and architects [12]-[18]. The Proceedings of the Seminars of Arabian Studies (PSAS) is another platform where some research about this architecture were published [11][19]-[24]. The fact that the architecture of forts and military structures, especially those built during AlYa'ariba Imamate, is a central reference to the Omani Contemporary Identity (As it shall be demonstrated in this research). This architecture is also featured in several other publications for the general public [25] [30]. Despite its largely descriptive character, this published material is a precious corpus based on which further studies in the historiography and the analysis of the development of Architectural styles in Oman can be undertaken.

\section{METHODS}

This research used an established methodology. The data required were collected by investigating the relevant literature and field surveys of the most representative forts, citadels, and palaces built by AlYa'ariba rulers. A comparative analysis between the military architecture in Oman and the region during the studied period allowed us to identify its architectural typology and development (Figure 1). The discussion focused on elaborating a reflection about the transformation of the defensive architecture during AlYa'ariba Imamate and its continuities in the Omani contemporary of "Sultanian Architecture". 


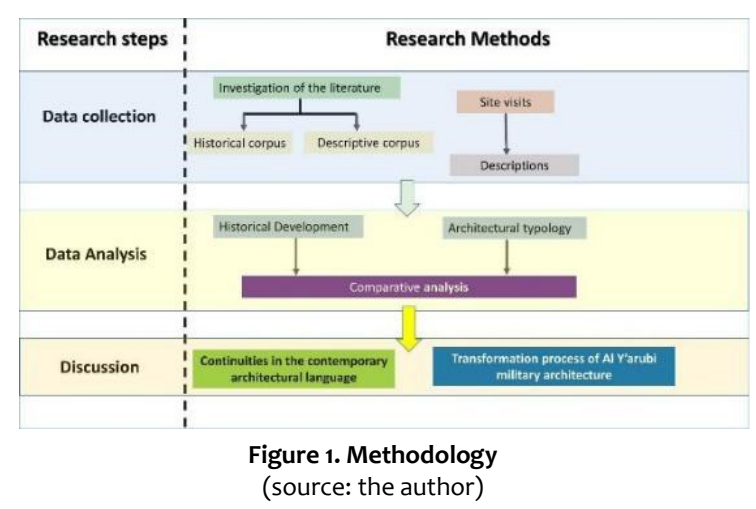

DISCUSSION HISTORICAL OVERVIEW

Oman has been a very active commercial pole in the region since millenaries. Research in history and archaeological surveys have demonstrated that the inhabitants of this land maintained solid trading ties with the Sumerians, Babylonians, and with the people of Egypt and the Indus Valley [14] [15] [31]. Islam settled in Oman during the Prophet Mohamed's (PBUH) lifetime, with the conversion of the two brother kings Jaifar and 'Abd, from the Al-Julanda Dynasty, in 630-632. The establishment of the first Ibadi Imamate in 751 in Oman was a decisive moment in the history. It deeply influenced the politics and social organization of the state that we know today [32] [33].

Ibadism was one of the earliest schools of thought (Mathab) in Islam. It was formed in Basra (Iraq) in the 7th century, then spread to the rest of the Arabian Peninsula and arrived at the Maghrib where the important Rustemid Imamate was founded with Tahart (in Actual Algeria) as the capital. The Imamate was a governing system based on the principle of election, which was proper to the Muslim communities. Following the Ibadi school of thought, this ruling system, inspired by the principle of "Shura" (consultation) in Islam, was developed throughout the history of Ibadism. An Imamate was a bilateral contract between the elected Imam and his community who gave him allegiance (Bay'a) after being chosen by the Ibadi scholars and men of influential opinion [34]. In virtue of this contract, the Imam was committed to leading his people following the prescription of the Quran, Sunnah, and the guidance of the Ibadi Figh. In return, the community was deemed to obey the Imam and followed his guidance without conditions as long as he fulfilled his duties. If the Imam failed in honoring the terms of this contract, he would be forced to step down from his position, and another Imam would be elected to replace him. Similarly, if community members refused to honor their part of the contract, they would be excommunicated. After the arousal of the Fatimid and the defeat of the Rustemid Ibadi Imamate was stated, the Ibadi fled to the region of Mzab (Algeria) as their ultimate quarters. The Ibadi school of thought is still active today in the Sultanate of Oman, The Mzab, Djerba Island (Tunisia), and Jebel Nafusa in Libya [32] [35]-[40].

Oman was the only region where the Ibadi Imamate continued, with more or less strength, until the 20th century [32][34][41]. While the Omani sailors maintained their domination over the Indian Ocean's shores and beyond, the interior cities of the country became centers for the propagation of Ibadism. Nizwa, Al Buraimi, and Rustaq flourished rapidly. During the 9th and 10th centuries CE, Oman was occupied by the Qarmatians, then by the Seljuks [42][44]. The migration of Omanis from the famous port of Sûr towards the oriental coasts of Africa reached its peak during this period. Chronicles reported that the cities of Mogadishu and Brawa were found by Omani families from the tribe of Al-Harthy who came from the city of Ibra in the A-Sharquiya region in Oman [15]. The riche productions of these newly conquered lands made the wealth of Oman and participated in the urban and architectural development of the mainland [32]. The maritime silk roads were at the origin of the expansion of the trading activities of Omanis in China and the Oriental African coasts. Omani sailors and cities were famous in the Indian Ocean long before the arrival of Europeans in the 16th century. Between Sohar and Dhofar, new cities came to life. The strategic character of the Strait of Hormuz as an essential passage between Asia and Europe stimulated the development of several coastal cities such as Qalhat and Tiwi [8] [11] [44].

Despite the long-lasting competition between the Persians and the Omanis over the control of the Arabian Sea coastal cities, Oman's economic growth will only be interrupted by the invasion of the ports of Quriyat, Muscat, and Sohar by the Portuguese in the first years of the 16th century. During their oriental expansion, between 1505 and 1509, the Portuguese captured Socotra Island and took control of Muscat and Hormuz, the important passage of the maritime routes to India and Gao. Due to the weakness of the Omani defences, other important coastal cities such as Quriyat, Qalhat, Zafar, Sûr, Ras Al Hadd, Sohar, and Muscat fell to the well-equipped Portuguese army led by Afonso de Albuquerque. Many of those cities were sacked and burned to the ground, and their population decimated [27]. Thus, the Portuguese terminated the 200 years long control of the kingdom of Hormuz over the Oriental Coastal strip of Oman. Their domination of the newly conquered territories would last for over 140 years, though intermittently challenged mainly by the Turks and the Persians [15]. The Portuguese introduced new techniques in constructing forts to withstand cannon artillery [15] [27]. The Omanis would later adopt them in the construction of their defensive structures.

During their occupation of Oman's coasts (from 1507 to 1650), the Portuguese succeeded in securing a long-lasting control of the maritime trading routes of the Indian Ocean through their strongholds implanted 
in strategic locations such as Muscat, Mutrah, Hormuz, or Sohar [15]. As a result, they beneficiated from all the transactions that were taking place in Oman's main ports and secured a safe passage of their fleets to the Iberian Peninsula, their homeland (Figure 2). Subsequently, the Omani economy, which heavily relied on this trading, witnessed a drastic setback, leaving the people, especially in the inner lands, in deep poverty [15] [45].

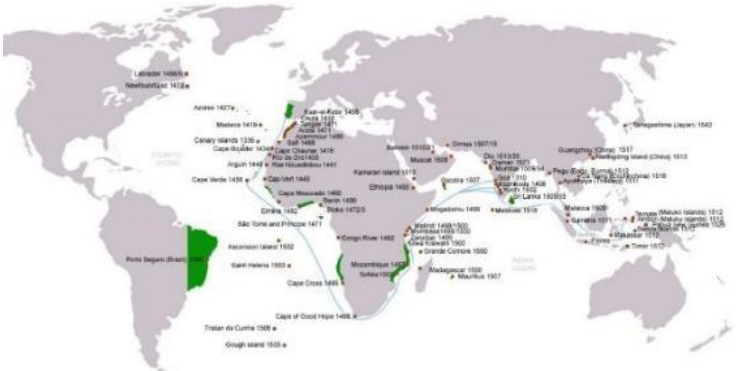

Figure 2. The Portuguese expansion in the $15^{\text {th }}-16^{\text {th }}$ centuries

By the end of the Al-Nabahina dynasty in 1624, Oman was weak and vulnerable. The major coastal center was under the control of the Portuguese, while the interior was troubled by continuous turmoil and intestine struggles [24][27]. The country was fragmented into several zones of intermittent influence and domination by the Portuguese, the Ottomans, the Safavid, and the strong Omani tribes. In the midst of these instabilities and threats, Nacer Bin Morshid AlYa'arubi was elected as an Imam in 1624 by an influential group of Ibadi scholars and military leaders [27]. Very rapidly, the new Imam received a unanimous allegiance (Bay'a) from the Omanis of the coasts and the interior. This bay'a marked the start of the Al-Ya'ariba (Ya'rubi) state, which was also known as the fifth Ibadi Imamate (1624-1749) ${ }^{1}$ (Figure 3). Al Hinai [46] stated that the Ya'ariba Imamate acquired strength from the religious and social 'Asabiya (solidarity). The concept of 'Asabiya was introduced by Ibn Khaldun in the second chapter of his Moqaddima (Introduction) $\left(14^{\text {th }} \mathrm{CE}\right.$ ). It is translated as "group solidarity", "group feeling'. It is usually founded on real or imaginary blood ties that link several groups of extended families, who would define themselves and act as a group in taking political positions or achieving common goals. The state was strong when this 'Asabiya was strong. It was weakened when this social and religious support became fragile [47]. The newly established Ya'rubi ruler first made of his homeland, Rustaq, the capital of his state, and stayed in its fort. From his capital, Nacer Bin Morshid focused his efforts on the unification of the whole country under the rule of the Ya'rubi Imamate. He then moved his capital to Nizwa, the ever-beating heart of Ibadism and long-lasting capital of Al Nabahina [15], and launched the offensive against the Portuguese. Their domination over the lands of Oman was terminated in 1652 by the Omani army of the second Ya'rubi Imam: Sultan Bin Saif Bin Malik (Ruled in 1649-1680). Al-Ya'ariba Imams reunited Oman's interior lands to its pacified coast and consolidated their State politically, militarily, and economically. Their era witnessed the development of agriculture through the multiplication of Falaj(s) ${ }^{2}$, the erection of forts and fortresses, the flourishment of trade, and the consolidation of their maritime power.

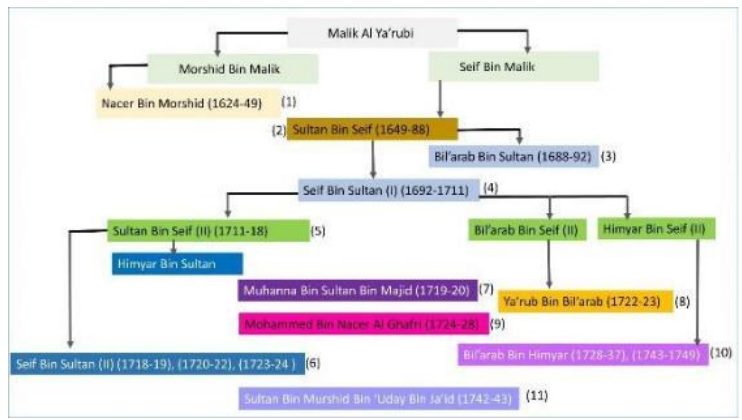

Figure 3. The Ya'rubi Imams genealogy. (By author based on multiple historical references)

During the $17^{\text {th }}$ century, the territory of the empire of Muscat and Oman expanded to the southern shores of Iran and Hormuz. It included Madagascar and East African lands that were once under the control of the Portuguese. The Omani merchants opened their outlets in China, India, and the Swahili coasts. They settled in Kilwa, Mombassa, Mogadiscio, and Zanzibar.

With Sûr, the latter became one of the great metropolises of international trade [12] [13]. It was worth mentioning that it was through these commercial channels that Islam and Ibadism reached those lands where Omanis were many respected merchants. While exploring west into the African continent, towards Burundi and Congo, the Omani merchants were kept solid ties with their homeland by sending money and rare products and also asking their relatives to build rich houses in their villages. The cities of Ibra and Mudayrib owe their urban development and their richly decorated mansions to this practice [12][13][49]. Thus, within less than a century, Oman witnessed one of its most important transformations as a State and a Nation. It moved from a poor, fragmented, and partially occupied country to a powerful and unified state with an expanding territory and growing wealth [24][27] [48] (Figure 4).

With the turn of the 18 th century, the Ya'rubi State had already started its phase of decline. The long internal rivalries between Ya'rubi Imams and other tribes' chiefs were exacerbated by Persian and Turkish intrusions and British and Dutch manipulations [4] [50]. As an influential military leader and high-ranked soldier in the last Al-Ya'arubi Imam (Bal'arab bin Himyar), Ahmad bin Said Al-Busaidi led the Omani and expelled the Persian from Muscat and Sohar. Consequently, he was declared Sultan of Muscat and 
Imam of Oman in 1749 [7] [27]. It marked the end of AlYa'ariba Imamate and the start of the Al-Said dynasty, which is still ruling Oman until today under his Majesty Sultan Haitham Bin Tariq Al Said (since 2020).

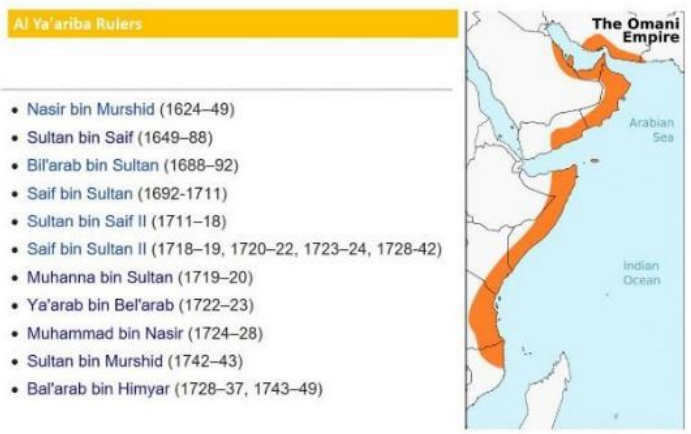

Figure 4. Al-Ya'ariba Empire $\left(18^{\text {th }}-19^{\text {th }}\right.$ centuries $)$

TRANSFORMATION OF THE MILITARY ARCHITECTURE IN OMAN DURING AL-YA'ARIBA IMAMATE

The Al-Ya'ariba period was a key stage in the history of military architecture in Oman between the $17^{\text {th }}$ and $18^{\text {th }}$ centuries [15][27][45]. During this time, the Omanis mastered constructing and transforming forts and fortresses to a typology that allowed the building to withstand the artillery. It is worth mentioning that among the factors that helped the Portuguese in taking hold of the Omani coasts was the fact that the Omani defensive structures of the time (such as Bahla fort) were not adequate to resist the new ballistic technologies which used cannons to fire heavy projectiles [15][27] (Figure 5). The new typologies and construction technics used by Al-Ya'ariba in their military structures helped resist the Portuguese' attacks and maintain a steady and continuous expansion over the lands they controlled.

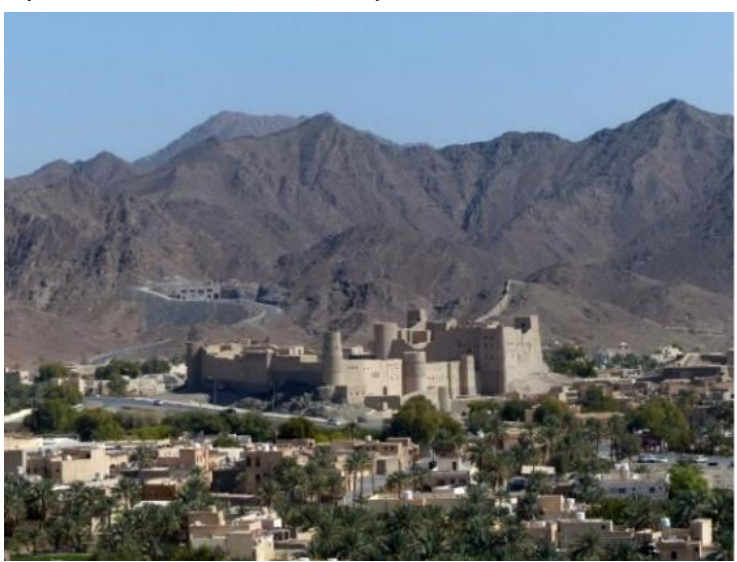

Figure 5. Fort of Bahla: example of pre-cannon forts in Oman

Nizwa fort, located in the capital city, is the most famous and among the first full-fledged antiballistic forts built by Al-Ya'ariba [27] (Figure 6). With its huge round tower, this fort is located in the center of the city to protect it and its surroundings better. With the other fortified palaces such as Al Hazm or Jabrin [4] [16][27][51], Nizwa fort presents a specific architectural typology that characterizes all military structures built during and even after Al-Ya'ariba Imamate (Figure 7). This fort and its typology will be further discussed in the sections below.

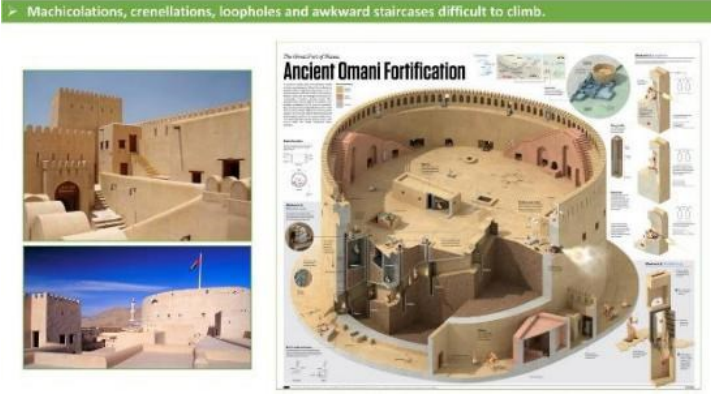

Figure 6. Defensive features of Nizwa fort (Composition by the author with infographics by Antonio Farach)

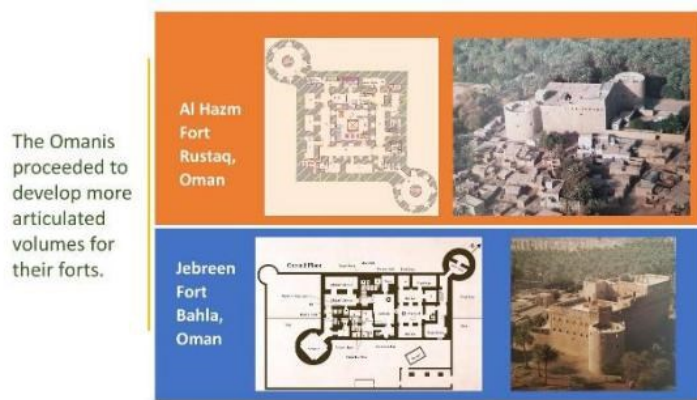

Figure 7. The forts of Al-Hazm and Jabrin (Composition by the author with plans from the Ministry of Heritage and tourism and photos from [40])

Since they took the leadership over the rest of the Omani tribes, Nacer Bin Morshid and his first Ya'rubi successors concentrated their efforts on the two major aspirations of the people of Oman: unifying the country and ensuring the country the availability of water and first necessity products. Therefore, they focused on developing and multiplying the water distribution systems (Aflaj) to irrigate the cultivated lands [27][52], while reinforcing the defensive and military structures throughout the country. In addition, the Ya'rubi Imams funded the edification of the largest and most prominent forts and fortresses, such as Nizwa, Rustaq, Nakhal, Jabrin, etc. Still, local tribes chiefs, encouraged by the Imams, also participated extensively in developing the defensive architecture in Oman during this period [27][51]. Thus, Al-Ya'ariba consolidated their defences and authority over Oman's interior before expanding their control over the coasts occupied by the Portuguese at the time. The main city in the interior is protected by one or more forts, generally located in the center of its territory and other strategic positions [27][45][53]. The important roads and passages between the coasts and the interior were also protected by a string of towers atop the surrounding hills to secure the movement between the cities. Through these actions, dedicated to protecting the people and their lands from the invaders, AlYa'ariba rulers restored the trust of the Omanis in their leaders. In addition, they strengthened the unity of all 
tribes living in Oman behind them. The transformations of the people's relationship with their rulers (Al-Ya'ariba Imams) and the technical revolution in the defensive structures have facilitated a decisive turnover in the balance of power between the Omanis and the Portuguese in Oman and the rest of the Portuguese colonies in Eastern Africa [15] [27] (Figure 4).

\section{THE ARCHITECTURAL TYPOLOGY OF THE OMANI FORTS AND} THEIR DEVELOPMENT

As stated by D'Errico, the architecture of the Omani pre-gunpowder forts developed from the Islamic military architecture of the Abbasids (750 1258) [15] (Figure 8). This architecture matured by integrating the styles of the neighboring powers at the time (Persians and Byzantines), and the tower specifically became an important feature of Islamic military architecture [15]. This architectural style spread from actual Iraq to reach the territories of the Muslim states in the Maghrib and Al-Andalus [15]. This military architecture spread further North from AlAndalus to reach Europe, where it will be extensively developed, especially during the crusades period [15].

D'Errico argues that the Aghlabid fort of Ribat Susa (the actual Tunisian city of Sousse) can be considered as the early typology of "pre-gunpowder" forts, which has influenced the military architecture in Islamic and European territories alike [15] ( Figure 9 ).

Major parts of south Europe evolved out of the dark ages thanks to the innovations made by Muslims in these regions

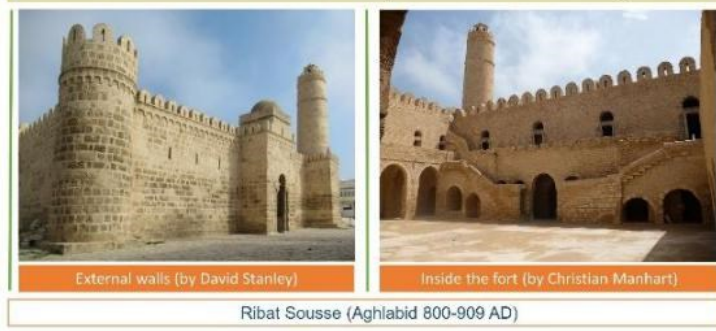

Figure 8. Fort of Susa: Aghlabid dynasty in Tunisia 8th century (Composition by the author from photos by: David Stanly and Christian Manhart)

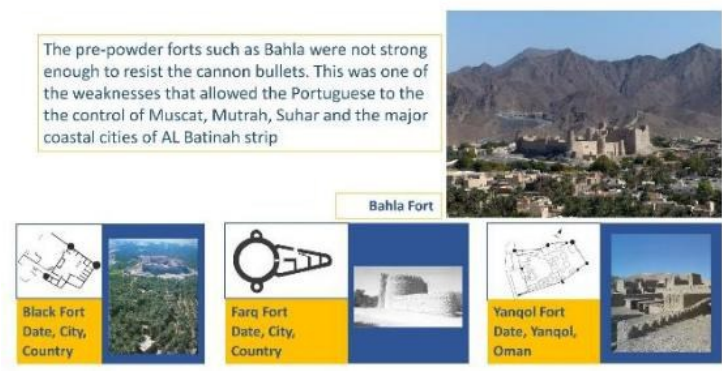

Figure 9. Examples of pre-gunpowder Forts from Oman.

(Composed by the author, plans, and pictures from

$$
\text { [40]) }
$$

Similarly, he asserted that the techniques of building forts that could withstand the new ballistic weaponry were developed during the European renaissance in the $16^{\text {th }}$ century of Italy. It would then spread to the rest of the European center of power [15]. Portugal was among those influential centers at the time. It was common practice that Spanish or Portuguese kings called upon Italian engineers to build their fortified palaces, forts, and fortresses [15] to defend their presence against their competitors in the region (Turks and Persians) [15] [54] [55], and secure their control over the Omani coasts. By extension over the maritime trading routes in the Indian Ocean, the Portuguese built two forts in Muscat (Al-Jalali and AlMirani in the 1580s) and the third one in Mutrah [27]. The inscription found on the lintel of Al Mirani Gate indicates 1588 as the consecration date of the fort under the reign of King Phillip I of Portugal, who was Phillip II of Spain [27]. However, Al Mirani and Al Jalali were started earlier and destroyed by the Turks' fleet [27]. Therefore, the dates of construction of Al Jalali and Al Mirani vary following the sources. The same uncertainty characterizes the origins of these forts and their initial builders. Some sources, especially Omanis, claim that Al Mirani, if not both forts, existed as fortified posts before the Portuguese built theirs [56]. All consulted references state that the Portuguese were at the origin of the Anti-Ballistic platforms in the forts. Based on 16th-century descriptions and maps, D'Errico asserts that the Portuguese built the core of the actual forts: the platforms for the cannons, some barracks for the weapons, and a small chapel. But the Ya'rubi gave these forts most of its actual articulated volumes [15]. They also consolidated their grip over a series of commercial center along the Al Batinah coast [15] [27]. After the termination of the Hormuz kingdom, whose domination over these coasts lasted for 200 years, the Portuguese did not have any ambition to go further in the interior lands of Oman [15] [27]. The strategic location at the two most tipping points of land in the sea of Oman gave the Portuguese complete control over the maritime traffic in the area [15][27].

D'Errico reported that the Portuguese used the services of an Italian engineer, who used to work in the king's court, to design and supervise the construction of Al Jalali and Al Mirani forts in Muscat [15] [57]. They also recruited Omani builders for this purpose [15][27]. It seems that the involvement of Omanis in the construction of Al Jalali and Al Mirani was at the origin of the "local Omani look" of these forts (Figure 10). While executing a general design that was new to them, the Omani builders, coming from a long-lasting tradition in construction, were able to leave their stamp on the architecture of these forts [15]. This "creative interpretation" of the technics of "the other" was described by Henri Saladin, who stated: « We could remark in this regard that when a new architecture is formed by the contact of two civilizations already ancient, where the construction methods have long ago reached a high level of relative perfection, but where the construction materials are different, the new architecture consists in the mere transposition of new decorative forms, while the construction methods 
remain the same as the local traditions. On the contrary, if the two civilizations in contact are of unequal cultures, the one that has the most advanced construction techniques will impose them, like Syria to Egypt in the $12^{\text {th }}$ CE, Persia to Mesopotamia in the 16th CE. and the Arab Spain to Morocco in the $12^{\text {th }}$ CE." [58]. We could imagine that the "local image" of the first forts built by the Portuguese in Muscat was, even partially, the fruit of this process of transmission between the two civilizations as described by Saladin. This explanation becomes more obvious when we compare the forts of Al Jalali and Al Mirani in Muscat to the other forts built by the Portuguese in Hormuz or along the west coast of Africa and India, where "Designs, volumes and indeed the stones might have been imported directly from Portugal" [15][59].

\section{The Ya'rubi forts typology}

The participation of the Omani builders in the edification of Al Jalali and Al Mirani facilitated the transfer of knowledge to the locals, which helped them develop the proper skills to build their antiballistic forts later on [15][51]. However, after integrating the Portuguese technology, the Omani new forts, built under the orders of Al-Ya'ariba Imams, was not defensive, like those of the pre-powder period, but they became offensive through their Machicolations, crenulations, loopholes, and zigzagging, as it was difficult to climb staircases [15] [27][53].

Due to the political circumstances in Oman at the time, Al Ya'ariba Imams lived in forts or fortified palaces that were transformed or newly built under their orders [4][15][27][51][60] [61]. These buildings were made of the same construction materials and had an architectural language common to the local Omani architecture. These construction's major defensive features consisted of towers, gates, and surrounding walls (Figure $6 \& 7$ ). The towers were made of large masonry walls with earthen mortar and cladded with a thick layer of plaster called "Sarooj"3. Commonly, the first level of such towers was laid on an earth-fill of several meters high. This technique was used to consolidate the resistance of the tower against the vibrations generated by the cannons detonations or the bullet impact on their walls. Furthermore, the elevation of the towers secured a dominant view from atop the structure and safeguarded its base from enemy intrusion. The surrounding walls were made of unbaked mud bricks over a stone foundation. The same binding and cladding materials as for the towers were also used for the surrounding walls. The flat roofs were made of a structure of palm tree logs (forming the beams) and a layer of palm leaves and fibers matting to support the mud and rubbles that form the thickness of the roof. Some parts of the structure, such as the stairs and specific rooms, might present ribbed or barrel-vaulted roofs, as in the Palace of Jabrin (or Jibrin) [16]. A final outer layer of Sarooj was added to waterproof the terraces. In many instances, these forts and fortified residences exhibit an overall image of strength, power, dominance, and austerity. In the reception spaces and private rooms, however, carved and painted woods in the ceilings, Sarooj panels engraved with floral and geometric patterns in some walls, impress the visitor by their beauty in spite of their relatively limited sophistication [4][16][27][51] [60]. Their solid structure and massive consolidated walls and towers, though built with the same materials as before, resisted the vibrations generated by the cannons' detonations and bullet impacts very well.

Nizwa fortress, with its huge tower, is the earliest example of such constructions built by the Omanis during Al-Ya'ariba Imamate. Nacer Bin Morshid attempted to restore the pre-existing fort in the Area of Al' Aqor in Nizwa, but its advanced state of deterioration complicated the restoration works. The fort took its actual form, with its imposing tower, in the late 1660's during the rule of the second Ya'rubi Imam Sultan Bin Saif (1649-1668) (Figure 3). The tower and the consolidations of the fort were funded with the spoils collected after defeating the Portuguese fleet [27]. Sultan Bin Saif first built the forts of Sohar, Liwa, and Bat before intervening in Nizwa fort [22][27]. The tradition of building huge round defensive towers in Oman goes back to the Third millennium [31][51][61]. The Archaeological excavations in Nizwa uncovered some fortified monuments from this period, which were used to control the access to the oasis [62]. It is probably based on this ground that Nizwa fort's tower has been related to these monuments [27][31] and even to the UNESCO listed tombs at Bat [63]. The instance of Nizwa tower illustrates the transfer process and influence of outsider's knowhow on the local architecture and savoir-faire. In contrast, the local forms, construction techniques, and materials are retained. The fortress of Nizwa is the first full-fledged Omani fort with a gunnery tower [15][27][51]. This model is refined and applied in other important forts such as Bidbid, Jabrin, or Al Hazm (Figure 7).

\section{THE PREVALENCE OF AL-YA'ARUBI MILITARY ARCHITECTURAL FORMS IN THE OMANI ARCHITECTURAL} IDENTITY

Warriors and religious leaders, Al-Ya'ariba Imams, guided their people in their religious rituals and the battlefields alike. Moreover, they used to travel throughout the unified Omani lands to confirm the allegiance of the tribes, consolidate their alliances and, if needed, fight any foreign opponent or a local insurgent who declared their opposition to the rule of the elected Imam. Therefore, Al-Ya'ariba rulers were keen to develop a well-organized and strongly connected network of defensive structures (such as forts, citadels, and fortified palaces) to cover the entire territory, especially the strategic passages through the wadis to inner Oman [15][27][45][53]. "... Fort Bidbid is the key at the coastal end of this defensive system, Nizwa fort is at the heart of this system in the interior, behind it, the forts were distributed following concentric lines facing the desert". [15] This network was not only meant to secure the territory and the 
agricultural lands cultivated by the population, but it was also a means to softly assert the presence and the domination of Al-Ya'ariba over the whole unified territory [15][27].

With the unification of the country, the consolidation of the State, and the accumulation of resources and expertise, the military architecture under Al-Ya'ariba has been refined into a proper local typology. D'Errico claimed that "This typology of Omani military architecture is part of a continuing Muslim tradition with examples from Balushistan to North Africa" [15]. On the other hand, in his comments on the architecture of Jabrin palace, Galdieri pointed out the "uniqueness" of the Palace's forms not without linking its decorative registers and techniques with a Safavid influence from Yazd [16][51].

The Ya'rubi forts' typology consists of a simple cubical or cuboid volume flanked by two towers in diagonally opposite corners. The two towers served as structural bracing and secured positions to control the building and its surroundings (Figure 7). The forts of $\mathrm{Al}$ Hazm, Jabrin, Bidbid, and Mutrah are significant examples of this typology [15][16][27][29]. The new construction techniques of anti-artillery bastions were applied on all these structures, whether they existed before Al-Ya'ariba and transformed into the new style (Fort of Rustaq), or were they initially erected by these rulers or their followers (Jabrin or Al Hazm forts).

Forts, towers, and fortresses, strongholds of the Imamate and symbols of its power, were also the refuge for the civilian Omanis when an armed conflict arises in a region [4][27][60]. Some Ya'rubi palaces such as Bait Al-Nu'man were used as residences for sultans and important travelers during their transit between the coast and the interior of the country [29]. Other forts, such as Jabrin palace or Nizwa fortress, were places where distinguished scholars dispensed higher education when they were not on the battlefield [4][15][27]. It was common that the Ya'rubi's most prominent generals were also erudite scholars in religion, Arabic, history, and even science. The chronicles have given the names and biographies of some of them, such as Imam Khamis A-Shaqsi of Rustaq, Ibadi scholar, and high-rank officer in the army of Imam Nacer Bin Morshid [65]. Al-Ya'ariba rulers were respected and had the allegiance and admiration of the population because they brought the country back to its unity and economic and political independence, and stability. Their forts and military structures became a source of pride and a symbol of strength for the Omanis [4][15][66]. In their civil architecture, the Omanis emulated the military architectural style of Al-Ya'ariba as part of the identity that they wanted to claim, when in the same period in Europe, the civilian architecture was distinguishing itself from the military building engineering [15].

Motifs taken from fort architecture are omnipresent in modern Oman's urban landscape. This "emulation" or "transfer" of the Al-Ya'ariba architectural language to the civilian buildings could have been enabled by three main factors: first, the
Ya'rubi style emanated from the "local" typologies and their architectural vocabulary, even if some important transformations were made after the contact with the Portuguese and the change in the artillery style. Second, the same local materials and construction techniques that the Omanis use for their residential buildings were used in these forts and palaces. Finally, as the Ibadi religious rules required, there was no excess in the size or ornamentation of the forts and palaces built by Al-Ya'ariba [67]. Therefore, it made it possible for the Omanis to use their architectural language in their buildings. This situation illustrates the influence of the architectural forms and vocabulary proper to Ya'ariba on the local architectural expression of the people, which emulates it to strengthen the symbolic inheritance of their legacy (Figure 10).

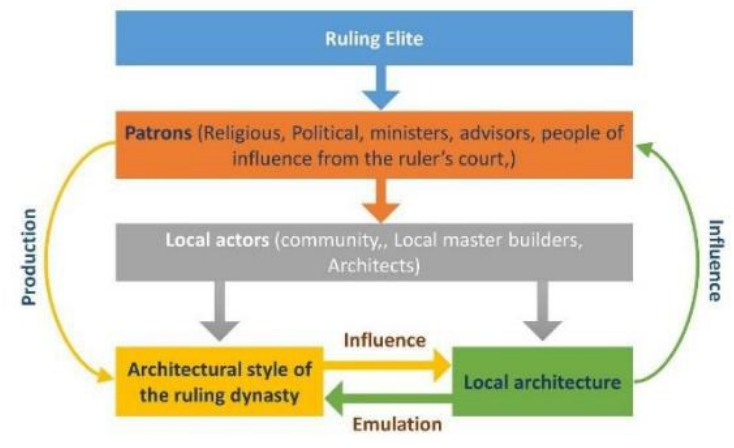

Figure 10. Process of formation and Transformation of the the architecture of power under Al-Ya'ariba (By the author)

It is possible that the same reasons were behind the adoption of the typology and architectonics proper to Al-Ya'ariba military architecture, by their successors Imams and Sultans of Al-Busaidi dynasty as it can be observed in forts and mentions they have built (Bait A- Nu'man, Bait Al 'Awabi, Bait Al Felij, etc.) [29]. Even today, Oman's official buildings are characterized by this military architectural vocabulary, where crenellations crown all types of buildings, and towers punctuate their corners [26]. The Omanis are attached to this symbol, which came to them when their country was the most powerful. It is their shared heritage, a source of pride [66], and, to a certain extent, it seems to be a symbol of the identity they want to claim [59] (Figure 11 \& Figure 12). An identity that links their present to their glorious past. This awareness has been continuously encouraged by the late Sultan Qaboos b. Said, who was at the top of the governmental decisions in this matter [68].

It is worth noting that, like the Al-Ya'ariba period, the reign of the late Sultan Qaboos Bin Said (died in 2020) was a turning point in Oman's economy and political status in the region since 1970. Thanks to the important Oil revenues, he could develop modern infrastructures and large industrial projects that made the Omanis deeply regard him. Like the Ya'rubi Imams, Sultan Qaboos travelled throughout Oman to meet his people and discuss directly with the tribes' leaders their problems and aspirations, even if, in his era, the role of the tribe chiefs became much weaker in the 
State's affairs than what it was under Al-Ya'ariba. He was also keen to develop a contemporary local architectural language in the country through the projects he funded through the office of Royal court affairs [63] [68]. As a result, buildings such as the Royal opera house, the Sultan Qaboos Grand Mosque in Muscat, or A-Shumukh fort in Manah, exhibit an architectural language, locally known as "Sultanian style", which is inspired from the military architecture at its highest and represent the architectural language of the official buildings in Oman today.

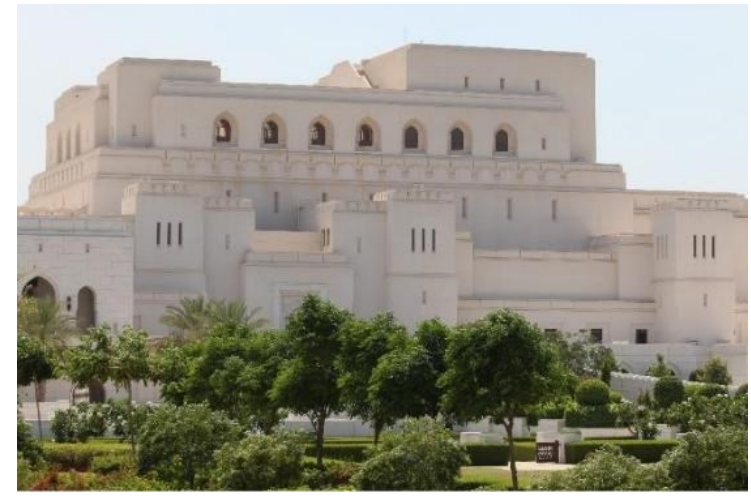

Figure 11. Examples of Sultanian style of architecture in Oman: Muscat Opera House.

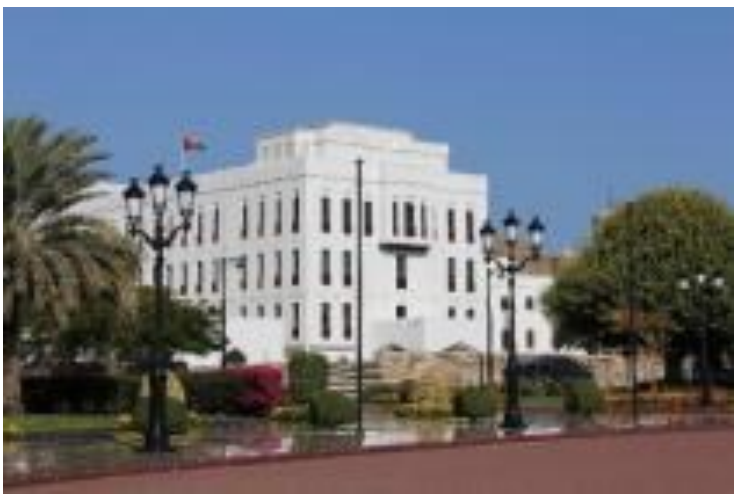

Figure 12. Examples of Sultanian style of architecture in Oman: The National Museum of Oman

\section{CONCLUSION}

This research discusses the different factors that led to the development of the architectural style of Al-Ya'ariba military architecture. It is still marking the identity of Oman's built environment. This research addresses the archetypical character and the continuity of its forms in today's civilian and official Omani architecture. Following a comparative and historical analysis, the research articulates an interpretation of the (trans) formation process of this architecture as being the result of complex operation of mutual influence, emulation, and creative interpretation between the ruling elite (in this case is Al-Ya'ariba) and the common people in Oman; or between different civilizations that come into contact with each other in a particular place and time, through military occupation (The Portuguese in Oman).

The finding of the research is to support the idea that architectural vocabulary and technological construction that were operated by the "Ruler" elite and featured in "official" architecture, influenced "popular" architecture, which would indeed monitor it following a different one. This interpretation is conditioned by the nature of the relationship between the local population and those in power. The most efficient construction technology will be integrated with local architecture no matter who introduces it in the region. However, the application of vocabulary follows a more complex process.

This research shows that when the Omanis confront the enemy, they took the technology introduced by the Portuguese (more efficient than them), but they built forts with the design inspired by local architecture. It is done to assert their identity against the invaders. Some of the resulting architectural features are drawn from the "dominant" architectural languages and techniques; they have been reinterpreted and reinvented with the local language. Omanis adapt their buildings to their local context, particular defence needs, and socio-political conditions. This process has allowed for a unique version of the fort fortification, which corresponds to the Omani empire in the 16th-17th centuries.

Furthermore, this research emphasizes the functional and chronologic transcendence of the symbols linked to the Ya'rubi military architecture. Today, it becomes constituent of the Omani architectural identity. The fact is that Al-Ya'ariba period was an era of stability, prosperity, and power. Because the Ya'rubi Imam is elected and the people paid them allegiance (Bay'a), the architectural style of their forts and palaces became a sort of model that the Omanis imitated in their residential architecture [15]. Until now, the contemporary architecture of Oman, including the civilian part, holds in its forms and architectonics some of the prominent references to the forts and citadels of the Ya'rubi era. Al-Busaidi sultans, successors of Al-Ya'ariba, perpetuates their predecessors' style in their mansions and other official buildings for the same reasons.

\section{ACKNOWLEDGMENTS}

This article is part of a research Project (CR/ENG) CAED/20/02), funded by The Sultan's School. The author's gratitude goes to Sultan Qaboos University for its continuous support. Deep appreciation is also expressed to the anonymous reviewers for their constructive comments and informed suggestions.

\section{REFERENCES}

[1] N. Rabbat, "What is Islamic architecture anyway?", J. Art Hist., vol. 6, pp. 1-15, 2012. 
[2] O. Grabar, "Reflections on the study of Islamic Art," Muqarnas, pp. 1-14, 1983, doi: https:// doi.org/10.2307/1523068

[3] B. S. Hakim, "Viewpoint: Urban form in traditional Islamic cultures: Further studies needed for formulating theory," Cities, vol. 16, no. 1, pp. 51-55, 1999, Doi: https:// doi.org/10.1016/S0264-2751(98)00054-7

[4] M. F. Mühlböck, "Forts and castles of Oman: Their importance for the defence of the imamate," Wien. Z. Kunde Morgenl, vol. 85, no. January 1st, pp. 233-238., 1995.

[5] S. B. Miles, The countries and tribes of the Persian Gulf, vol. 2. Harrison and sons, 1919.

[6] . Batuta, Voyages: De La Mecque aux steppes russes, vol. 51. F. Maspero, 1982.

[7] Salil-Ibn-Razik, History of the Imams and Seyyids of'Oman by Salil-ibn-Razik, from AD 661-1856, Routledge. New York, London: Taylor \& Francis Group, 2017.

[8] M. R. Bhacker and B. Bhacker, "Qalhãt in Arabian history: context and chronicles," J. Oman Stud., vol. 13, pp. 11-55, 2004.

[9] J. R. Wellsted, Travels in Arabia, vol. 1. London, Murray, 1838.

[10] J. G. Lorimer, Gazetteer of the Persian Gulf,' Omān, and Central Arabia, vol. 1\&2. Superintendent Government Print., India, 1917.

[11] D. Agius, "Medieval Qalhat: travellers, dhows and stone anchors in south-east Oman," Archaeol. Seafar., pp. 173-220, 1999.

[12] P. Bonnenfant and C. Le Cour Grandmaison, "The Ibra and Mudayrib Area," Journal of Oman Studies Studies. Ministry of National Heritage and Culture, Sultanate of Oman, pp. 91-94, 1977.

[13] P. Bonnenfant, G. Bonnenfant, and S. ibn H. ibn S. Al-Harthi, "Architecture and social history at Mudayrib," J. Oman Stud., vol. 3, Part 2, pp. 107 $-135,1977$.

[14] P. M. Costa, "Notes on settlement patterns in traditional Oman," J. Oman Stud., vol. 6, pp. 247 $-268,1983$

[15] E. D'Errico, "Introduction to Omani military architecture of the sixteenth, seventeenth and eighteenth Centuries," J. Oman Stud., vol. 6, pp. 291-306, 1983.

[16] Galdieri Eugenio, "A Masterpiece of Omani 17th Century Architecture," J. Oman Stud., vol. 1, no.
1, pp. 167-179, 1975.

[17] M. Kervran, "Archaeological research at Suhar 1980-1986," J. Oman Stud., vol. 13, pp. 263-381, 2004.

[18] M. Kervran, C. Le Cour Grandmaison, M. Soubeyran, and A. Viallatte de Pemille, "Suhari Houses," J. Oman Stud., pp. 307-325, 1983.

[19] J. Schreiber, "Archaeological Survey at Ibra in The Sharqiyah, Sultanate of Oman," Proc. Semin. Arab. Stud., vol. 35, pp. 255-270, 2005.

[20] B. Mershen, "Settlement Space and Architecture in South Arabian Oases Ethnoarchaeological Investigations," in Proceedings of the Seminar for Arabian Studies, 1998, vol. 28

[21] M. S. Goffriller, M. Hongjiao, S. Bandyopadhyay, and J. Henderson, "Chinese porcelains and the decorations of Omani mihrabs," Proc. Semin. Arab. Stud., vol. 45, pp. 1 $-16,2015$.

[22] M. Kervran, "Deux Forteresses Islamiques de la Côte Orientale De L'Arabie," in Proceedings of the Seminar for Arabian Studies (Vol. 13), 1983, pp. 71-77.

[23] S. Bandyopadhyay, G. Quattrone, and H. N. AlAbri, "In times of war: typological and morphological characteristics of dwellings in âarat al-Yemen in Izkī, Oman," Proc. Semin. Arab. Stud., vol. 43, pp. 27-45, Nov. 2013.

[24] A. Al-Salimi, "Different succession chronologies of the Nabhāni dynasty in Oman," in Proceedings of the Seminar for Arabian Studies (Vol. 32), 2002, pp. 259-268.

[25] H. Gaube, "Settlements," in Islamic Art in Oman, A. Al-Salimi, H. Gaube, and L. Korn, Eds. Muscat: Mazoon Printing, Publishing \& Advertising LLC, 2014

[26] M. Al-Zubair, Oman's Architectural Journey. Muscat: BAZ Publishing, 2013.

[27] Al Qila', Al Qila' wal husun fi Oman. Muscat: Maktabu Dirosat, Na'ibu Roisu al-Wizaro' Li Su'uni Majlis al-Wizaro' - Qism Dirosat, 1994.

[28] S. Bandyopadhyay, Manah: Omani Oasis, Arabian legacy; architecture and social history of an Omani Oasis settlement. Historical Association of Oman \& Liverpool University Press, 2011

[29] M. A. Biancifiori, Biancifiori: works of architectural restoration in Oman. Edizioni De luca, 1994. 
[30] S. Samar Damluji, The architecture of Oman. 1998.

[31] C. M. Cable and C. P. Thornton, "Monumentality and the third-millennium 'towers' of the Oman Peninsula," in Connections and Complexity, New Approaches to the Archaeology of South Asia, Xx-xx. Pre., S. Abraham, P. Gullapalli, T. P. Raczek, and U. Z. Rizvi, Eds. Left Coast Press Walnut Creek, CA, 2013, pp. 375-399.

[32] N. Benkari-Boudidah, L'Architecture des mosquées Ibadites: M'zab, Djerba et Oman. Principes de conception et de construction, vol. 1. Saarbrücken: Saarbrücken: Presses académiques francophones., 2013.

[33] F. Scholz, "Oman-a model of democratic development in the Arabo-Islamic world?" Arab World Geogr., vol. 21, no. 1, pp. 83-92, 2018. Doi: https://doi.org/10.5555/1480-6800.21.1.83

[34] P. Cuperly, Introduction à l'étude de l'Ibä?isme et de sa théologie. Alger: Off. des Publ. Universitaires, 1984.

[35] J. C. Wilkinson, "Changement et continuité en Oman. La péninsule arabiquee," Editions C., P. Bonnenfant, Ed. Paris, 1980, pp. 394-395.

[36] V. J. Hoffman, "Ibā⿴lism: History, Doctrines, and Recent Scholarship," Relig. Compass, vol. 9, no. 9, pp. 297-307, 2015, doi; https://doi.org/10.1111/ rec3.12164

[37] T. Lewicki, "al-Ibadiyya," in Encyclopedia of Islam., and W. H. PJ Bearman, Th. Bianquis, CE Bosworth, E. van Donzel, Ed. London; Leiden: Leiden-Brill., 1971, pp. 648-660.

[38] T. Lewicki, "The Ibádites in Arabia and Africa: Part I. The Ibádí Community at Basra and the Origins of the Ibádite States in Arabia and North Africa, Seventh to Ninth Centuries," Cah. d'Histoire Mond. J. World Hist. Cuad. Hist. Mund., vol. 13, no. 1, p. 51, 1971.

[39] T. Lewicki, "Une chronique ibadite: Kitâb as Sijar, d'Abû-I (Abbas Ahmad as-Sammahi),"Rev. des études Islam., pp. 59-78, 1934.

[40] T. Lewicki, "Les Iba?ites dans l'Arabie du sud au moyen-age," in Akten des vierundzwanzigsten Orientalisten-Kongresses München 28. August bis 4. September 1957, H. Franke, Ed. Berlin Wiesbaden: Deutsche Morgenländische Gesellschaft, 1959, pp. 362-364.

[41] J. C. Wilkinson, "The Iba?i imama," Bull. Sch. Orient. African Stud., vol. 39, no. 3, pp. 535-551, 1976.
[42] N. Benkari-Boudidah, L'architecture des mosquées Ibadites au M'Zab, Djerba et Oman Tome II: Lecture des Principes de Conception et de Construction. Presses Académiques Francophones, 2014.

[43] M. Kervran and V. Bernard, "Mi?rāb/s omanais du $16 \mathrm{e}$ siècle: un curieux exemple de conservatisme de l'art du stuc iranien des époques seldjouqide et mongole," Archéologie Islam., vol. 6, pp. 109-156, 1996.

[44] A. Rougeulle, T. Creissen, and V. Bernard, "The Great Mosque of Qalhāt rediscovered. Main results of the 2008-2010 excavations at Qalhāt, Oman," in Seminar for Arabian Studies (Vol. 42), 2012, pp. 341-356.

[45] N. Benkari, "The defensive vernacular settlements in oman, a contextual study," Int. J. Herit. Archit. Stud. Repairs Maintence, vol. 1, no. 2, pp. 175-184, 2017, doi: 10.2495/HA-V1-N2-175184

[46] A. Ibn Khaldun, Al Muqaddimah (An introduction to history). Princeton: Princeton University Press.

[47] A. A. Al-Hinai, "The Ya'ariba Dynasty in Oman (1624-1744). A Khaldunian Perspective,” Bonn, 1998.

[48] J. Kirkman, "The Early History of Oman in East Africa," J. Oman Stud., vol. 6, p. 53, 1983.

[49] C. Le Cour Grandmaison, "Spatial Organization Tribal Grouping and Kinship in Ibra," J. Oman Stud., vol. 3, pp. 95-106, 1977.

[50] K. S. Salibi, A History of Arabia. Caravan Books, 1980.

[51] L. Korn, "Fortifications and Palaces," in Islamic Art in Oman, 3rd Editio., L. (Editors) Al-Salimi, A., Gaube, H., \& Korn, Ed. Mazoon Printing, Publishing and Advertising, Sultanate of Oman, pp. 118-151, 2014.

[52] M. Nagieb, S. Siebert, E. Luedeling, A. Buerkert, and J. Haser, "Settlement History of a Mountain Oasis in Northern Oman- Evidence from Land-Use and Archaeological Studies," DIE ERDE, vol. 135, no. 1, pp. 81-106, 2004

[53] P. Groves, Strongholds of Heritage: Forts and Castles of Oman. Motivate Publishing, 2010.

[54] F. Braudel, The Mediterranean and the Mediterranean World in the Age of Philip II, trans, vol. 2 Volumes. Glasgow: William Collins, 1972.

[55] R. B. Serjeant, The Portuguese off the South 
Arabian coast: [a]rami chronicles; with Yemeni and European accounts of Dutch pirates off Mocha in the seventeenth century. Oxford: Clarendon Press, 1963.

[56] M. A. K. Al-Belushi, "The heritage prospective and urban expansion in capital cities: old defence sites in Muscat, Oman," WIT Trans. Built Environ., vol. 131, pp. 551-562, 2013.

[57] C. R. Boxer and C. Azevedo, Fort Jesus and the Portuguese in Mombasa, 1593-1729. London: Hollis and Carter, 1960.

[58] S. Henri and M. Gaston, Manuel d'art musulman. Paris: A. Picard, 1907.

[59] J. M. Willis, "History, Culture, and the Forts of Oman," Arab Study Journal- Dirosat alArabiyah, pp. 141-143, 1996.

[6o] Y. Salim and Y. S. Al-Busaidi, "The protection and management of historic monuments in the Sultanate of Oman: the historic buildings of Oman," in Proceedings of the Seminar for Arabian Studies (Vol. 34), 2004, vol. 34, no. July 2003, pp. 35-44.

[61] M. E. Limbert, "Caste, Ethnicity, And the politics of arabness in southern arabia," Comp. Stud. South Asia, Africa Middle East, vol. 34, no. 3, pp. 590-598, 2014.
[62] J. Schreiber, "Transformation processes in oasis settlements in Oman' 2005 archaeological survey at the oasis of Nizwã: a preliminary report," in Proceedings of the Seminar for Arabian Studies, vol. 37, pp. 263-275, 2007.

[63] D. (Sir) Hawley and R. Muir, Oman: 4oth Anniversary Edition. London: Stacey International, 2012.

[64] P. M. Costa, “Bayt Na'mân, a seventeenth century mansion of the Ba?inah," J. Oman Stud., vol. 8 part 2, pp. 195-210, 1985.

[65] N. Benkari, Harats Qasra, Hujrat Musalmat, Al Khabt \& Sayja: Documentation and Heriage Management Plan. Muscat: Ministry of Heritage and Tourism, 2021.

[66] M. Limbert, In the time of oil: Piety, memory, and social life in an Omani town. Stanford University Press, 2010.

[67] N. Benkari, "A Document of Ibadi Figh Governing the Architecture of Mosques," J. Islam. Archit., vol. 4, no. 2, pp. 5662., 2016. DOI: https://doi.org/10.18860/ jia.v4i2.3487

[68] N. Benkari, "Oman," in Time Frames: Conservation Policies for Twentieth-Century Architectural Heritage, pp. 162-164, 2017. 